\title{
Universiteit
}

Leiden

The Netherlands

\section{Motor imagery during hypnotic arm paralysis in high and low hypnotizable subjects.}

Roelofs, K.; Hoogduin, C.A.L.; Keijsers, G.P.J.

\section{Citation}

Roelofs, K., Hoogduin, C. A. L., \& Keijsers, G. P. J. (2002). Motor imagery during hypnotic arm paralysis in high and low hypnotizable subjects. International Journal Of Clinical And Experimental Hypnosis, 50(1), 51-66. Retrieved from https://hdl.handle.net/1887/14460
Version:
Not Applicable (or Unknown)
License:
Leiden University Non-exclusive license
Downloaded from:
https://hdl.handle.net/1887/14460

Note: To cite this publication please use the final published version (if applicable). 


\title{
MOTOR IMAGERY DURING HYPNOTIC ARM PARALYSIS IN HIGH AND LOW HYPNOTIZABLE SUBJECTS
}

\author{
KARIN ROELOFS, ${ }^{12}$ KEES A. L. HOOGDUIN, \\ AND GER P. J. KEIJSERS ${ }^{12}$ \\ University of Nijmegen, the Netherlands
}

\begin{abstract}
Previous research suggests that conversion disordered patients with hand/arm paralysis exhibit slowed reaction times for mental hand-rotation tasks that correspond to their affected arm when the tasks are explicitly instructed and not when they are implicitly cued. Because of the many similarities between hypnotic phenomena and conversion symptoms, the authors tested whether similar motor imagery impairment would occur among normal high hypnotizable subjects when paralysis is suggested. Nine high and 8 low hypnotizable subjects were administered an implicit and an explicit mental hand-rotation task during hypnotically suggested paralysis of the right arm. On the implicit task, there were no significant reaction time (RT) differences between highs and lows. On the explicit task, only highs showed a significantly larger RT increase per degree of rotation with the paralyzed arm, compared to the normal arm. These preliminary findings suggest that the motor imagery impairment observed in conversion paralysis can be induced in highs using hypnosis.
\end{abstract}

Conversion paralysis is characterized by an inability to voluntarily move a body part in the absence of physical and neurological causes. Psychological factors, such as a traumatic event or prolonged exposure to stressful conditions, are suggested to be associated with the onset or exacerbation of the symptoms (American Psychiatric Association, 1994). Currently, several authors suggest that under these circumstances implicit and explicit information processes become dissociated in patients with conversion disorder (Kihlstrom, 1992a; Nemiah, 1993; Schacter \& Kihlstrom, 1989; Spiegel, 1990). According to Kihlstrom's dissociation theory of conversion disorder, the explicit or intentional information processes are impaired, whereas the implicit or automatic processes remain intact (Kihlstrom, 1992a, 1992b). Although a patient with conversion paralysis typically cannot intentionally move, under

Manuscript submitted September 5, 2000; final revision received March 19, 2001.

${ }^{1}$ The authors gratefully thank Hubert Voogd for computer support.

${ }^{2}$ Address correspondence to Karin Roelofs, Department of Clinical Psychology and Personality, University of Nijmegen, P.O. Box 9104,6500 HE, Nijmegen, the Netherlands, or Roelofs@psych.kun.nl.

The International Journal of Clinical and Experimental Hypnosis, Vol. 50, No. 1, January 2002 51-66

(C) 2002 The International Journal of Clinical and Experimental Hypnosis 
particular circumstances he or she is able to show some automatic movement, for example during sleep (Lauerma, 1993) and sometimes during hypnosis (Kihlstrom, 1992a; Moene, Hoogduin, \& Van Dyck, 1998).

Similar dissociations between automatic (implicit) and intentional (explicit) processes are also observed among highly hypnotizable subjects given suggestions for paralysis. Indeed, several authors such as Bliss (1984), Nemiah (1993), and Oakley (1999) considered conversion disorder to be a form of auto-hypnosis. Hypnotic phenomena and conversion symptoms may share some phenomenological features (for an overview, see Oakley, 1999). Two recent brain-mapping case studies suggest that similar brain structures are involved in conversion paralysis and hypnotic paralysis. In both conversion paralysis (Marshall, Halligan, Fink, Wade, \& Frackowiak, 1997) and hypnotically suggested paralysis (Halligan, Athwal, Oakley, \& Frackowiak, 2000), the right primary motor cortex showed a decreased activation when the subjects attempted to move their paralyzed (left) leg. This was accompanied by an increased activation in the right anterior cingulate cortex and the right orbito-frontal cortex. In both cases, the results were interpreted as indicating an inhibition of prefrontal (willed) effects on the primary motor cortex when a patient with conversion paralysis or a subject with hypnotically induced paralysis intentionally attempts to move. In sum, the empirical evidence for a relation between conversion symptoms and hypnotic phenomena is still preliminary, but the findings from these two case studies suggest that in conversion paralysis and hypnotic paralysis the linkage between higher-level and lower-level information processing is impaired, resulting in disturbances that predominantly affect the intentional motor functions.

As far as conversion paralysis is concerned, the findings of a motor imagery study (Roelofs et al., 2001) supported this hypothesis by showing explicit (i.e., intentional) motor processes to be impaired in 6 patients with conversion paralysis. Motor imagery or mental movement is important for the planning and preparation of movement and activates brain structures that overlap with those activated during real movement (see Jeannerod, 1997). In the motor imagery study by Roelofs and colleagues (2001), mental movement was both implicitly and explicitly cued. All tasks were computer administered. In the implicit motor imagery task, conversion disordered patients were presented with rotated pictures of left and right hands and instructed to identify as quickly as possible which hand was shown by saying "left" or "right." Several brain-mapping studies have shown this task to activate neural structures associated with real arm rotations (Decety et al., 1994; Parsons \& Fox; 1998; Parsons et al., 1995; Porro et al., 1996). The task is therefore designed to implicitly evoke mental arm rotations (Parsons et al., 1995; Parsons, Gabrieli, Phelps, \& Gazzaniga, 1998). In the explicit motor 
imagery task, patients were again presented with the pictures of hands but now with the explicit instruction to mentally move their own hands from a neutral position toward the target position and to say "yes" when the target position had been reached. Reaction times were recorded using voice-key registration.

In patients with general neurological motor pathology, such as Parkinson's disease, the reaction time (RT) profiles on the implicit motor imagery task are similar to those in tasks where motor imagery is explicitly instructed. In both implicit and explicit tasks, the unilaterally affected patients show a motor imagery asymmetry with a slowing of the affected arm (Dominey, Decety, Broussolle, Chazot, \& Jeannerod, 1995). However, the patients with conversion disorder in the Roelofs et al. (2001) study were significantly slower when mentally moving their most severely affected arm only in the explicit hand-rotation task. This effect did not occur in the implicit motor imagery task. The findings suggested that among conversion patients motor processing is especially impaired when it is explicit or intentional rather than when it is implicit or automatic.

The purpose of the present study was to investigate whether hypnotically suggested paralysis among normal, highly hypnotizable subjects is associated with impaired motor imagery, similar to that found for conversion disordered patients. If the phenomenological and neurophysiological similarities between conversion paralysis and hypnotically induced paralysis noted to date reflect a similar process at work, we expected to find motor imagery asymmetry (longer RTs for the paralyzed arm) in highly hypnotizable subjects who were given suggestions concerning arm paralysis. Second, we hypothesized that this motor imagery asymmetry in highly hypnotizable subjects would be significant only when motor imagery was explicitly instructed and not when it was implicitly evoked. This pilot study is designed to further explore these hypotheses.

\section{METHOD}

\section{Participants}

Nine high hypnotizable and 8 low hypnotizable subjects were selected from 135 students involved in a normative study of the Stanford Hypnotic Susceptibility Scale, Form C (SHSS:C; Weitzenhoffer \& Hilgard, 1962; see Näring, Roelofs, \& Hoogduin, 2001). The participants were all right-handed females. To enable comparison of paralyzed and normal arms, we needed subjects in both groups to respond to suggestions for hypnotic paralysis. Therefore, an additional inclusion criterion was that the subjects pass the arm catalepsy item of the SHSS:C (Item 5). Of these subjects, 9 of the highest (scoring 7 or more) and 9 of the lowest 
(scoring 3 or less) hypnotizable subjects met the criteria. One low hypnotizable subject dropped out before the experiment because of illness. The mean score of the low hypnotizables on the SHSS:C was 2.4 $(S D=0.52$, range 2 to 3$)$ and of the highs was 8.7 ( $S D=1$, range 7 to 10$)$. The mean age of lows and highs was $22.1(S D=2.3)$ and $22.3(S D=3.6)$, respectively. All participants provided their informed consent and received $\$ 10$ for their participation.

\section{Procedure}

The experiment was administered in the same room where the subjects had previously been hypnotized as part of the SHSS:C screening procedure. Prior to the experiment, the handedness of the participants was assessed. Following the motor imagery training procedure by Dominey et al. (1995), the participants were then familiarized with motor imagery instructions and trained for motor imagery using two imagery questionnaires that require the performance of mental movements. Subsequently, the subjects were seated in front of a computer. The arm paralysis was induced separately before the test phase of each task. Because the explicit instructions for mental hand rotations in the explicit task are likely to influence the strategy used on the implicit task, the implicit task was administered first. Patients were allowed a standard 10-minute break between the two computer tasks.

Arm paralysis. After the instructions and practice phase of both computer tasks, the senior experimenter (C.H.) entered the room and explained that he was going to use techniques similar to the previous hypnosis test (SHSS:C). After asking the participant's permission to touch his or her right arm, the experimenter induced a catalepsy of the right arm using the reversed hand levitation procedure described by Sacerdote (1970). This tactile catalepsy procedure is a hypnotic induction technique designed to elicit arm immobility and relaxation (Sacerdote, 1970). The subject was seated in a chair with the elbow on the armrest. The experimenter took the (right) wrist between the index finger and thumb. He lifted the forearm to a vertical position and induced catalepsy by alternately supporting or releasing the forearm (Sacerdote, 1970). Within a few minutes, all of the subjects reported changes in the perception of the arm (e.g., a sensation that the arm felt detached from the body). The hypnotist then checked for catalepsy, a characteristic state of the arm in which the arm returns to its elevated position when slightly pushed down. Next, he suggested feelings of stiffness of the right arm for the duration of the computer task. We had decided not to suggest arm paralysis in a direct way in order to minimize the demand characteristics of the task. The reversed hand levitation procedure, as well as the suggestion of stiffness of the arm, (indirectly) function as suggestions of an inability to move. The experimental sessions were videotaped to check whether the right arm remained in its position. 


\section{Materials}

Handedness questionnaire. Hand preference was assessed using the Annett's Handedness Questionnaire (Annett, 1970). It was scored using the method described by Lishman and McMeekan (1976).

Imagery questionnaires. The motor imagery training procedure was conducted using the Sheehan Imagery Questionnaire (SIQ; Sheehan, 1967) and the Movement Imagery Questionnaire (MIQ; Hall, Pongrac, \& Buckholz, 1985). The SIQ measures the ability to imagine a variety of perceptual and motor experiences. The MIQ measures the quality of imagery for 18 items involving the real performance of a movement followed by the mental performance of the same movement. Only those items involving an isolated arm movement were used (Items 1,5,10, and 14).

Computer tasks. The computer tasks were programmed for a Macintosh computer (LC475) using Symantec C++ for Macintosh and C_Frame, a package for implementing real-time experiments (see Voogd, 1995). Both tasks were preceded by instructions presented on the computer screen, an example with feedback, and a practice phase in which all task stimuli were shown once. The stimuli appeared in the center of the screen and remained visible until the participant responded using a voice key attached to a headset. RTs were recorded by means of an electronic timer with an accuracy of approximately $1 \mathrm{~ms}$. The experimenter, unaware of the hypnotizability (high or low) of the subject, recorded each answer and started the next stimulus presentation. The stimulus presentations were preceded by the presentation of a fixation point in the center of the screen, lasting $300 \mathrm{~ms}$, followed by a blank screen, which lasted $200 \mathrm{~ms}$. The participants were seated in a chair with lengthened armrests. Because the actual position of one's body influences the time needed to mentally perform a movement (Parsons, 1994), for the duration of the experiment the participants were asked to position their hands on the armrests, palms down and pointing forward. The distance between the participants' eyes and the center of the screen was $75 \mathrm{~cm}$.

Task 1: Implicit hand rotation. This decision task involves the implicit mental rotation of hands (Parsons, 1994; Parsons et al., 1995; Parsons et al., 1998). The stimuli were Parsons's line drawing pictures of hands ( $6.5 \mathrm{~cm}$ high and $5 \mathrm{~cm}$ wide). Both "palm" and "back" versions of the left and right hands were presented at eight rotation angles ranging from $0^{\circ}$ to $315^{\circ}$ with $45^{\circ}$ increments. The participants were instructed to decide as quickly and as accurately as possible whether the presented hand was a left or right hand by loudly and clearly saying "left" or "right." In the test phase, all possible presentations of the hands ( 2 hands $\times 2$ versions $\times 8$ angles $=32$ ) were presented twice. The stimuli were randomly assigned to blocks of eight hands and the blocks were presented in a random order. 
Task 2: Explicit hand rotation. In order to investigate the explicit motor imagery in hypnotic paralysis, the participants were presented with the hand stimuli of Task 1 but now with the explicit instruction to mentally rotate their hands in a natural and efficient manner without actually moving to the positions presented on the screen and to say "yes" when they had reached the target position. The procedure for stimulus presentation was the same as in Task 1, except that the stimuli were randomly presented in blocks of left hands and right hands. The blocks were presented in a random order. The experimenter stayed present to ensure that no movements were actually made. In addition, the sessions were recorded on videotape.

\section{Data ANALYSes}

Not the direction but the length of rotation was of interest for the present study. Because the $45^{\circ}$ and $315^{\circ}, 90^{\circ}$ and $270^{\circ}$, and $135^{\circ}$ and $225^{\circ}$ rotations equally differ from the $0^{\circ}$ position, the data were collapsed for each pair. This resulted in five orientation differences (ODs) of $0^{\circ}, 45^{\circ}, 90^{\circ}$, $135^{\circ}$, and $180^{\circ}$. On each task, RTs greater than two standard deviations from the individual mean RT per OD were attributed to distraction or a loss of attention and therefore excluded from the analyses. For each participant, the mean RT of the correct responses was then calculated per OD for both tasks.

In mental rotation tasks, the RT is found to linearly increase as a function of the angle of rotation (Shepard \& Cooper, 1982; Shepard \& Metzler, 1971). As a method for data reduction, individual regression analyses for RT by OD were conducted, resulting in two variables per person. The slope of the regression function is the relative RT increase per rotation degree, which provides an estimate of the rate at which the mental manipulation can be carried out. The intercept is the estimated RT without rotation load, which corresponds to an estimate of the time needed to imagine the target hand without mentally moving it (Shepard \& Metzler, 1971). Individual regression analyses were conducted for the good (left) arm and the paralyzed (right) arm.

To test our hypothesis that mental imagery of the paralyzed arm is slower in high hypnotizables, the individual intercepts associated with the normal and the paralyzed arm were put to a one-tailed MANOVA with group (lows, highs) as between-subject factor and arm (normal, paralyzed) as within-subject factor. We used a one-tailed criterion because of the strong directional hypothesis derived from findings with conversion disordered patients and because outcome in the wrong tail is meaningless and can be dismissed as a chance occurrence (Abelson, 1995).

To test our hypothesis that the slowing associated with an increase in angle of rotation is larger for motor imagery of the paralyzed arm in high 
hypnotizables, the individual regression slopes for both arms were put to a one-tailed MANOVA with group as between-subject factor and arm as within-subject factor.

\section{RESULTS}

\section{Implicit Hand-Rotation Task (1)}

The mean $R^{2}$ for the high hypnotizables' regression lines was .67 for the normal and . 49 for the paralyzed arm. For lows, the mean $R^{2} s$ were .58 for the normal arm and .50 for the paralyzed arm. Highs responded incorrectly in $3.8 \%$ (11) of the trials and lows in $3.1 \%$ (8).

\section{RT Intercept}

A two-way MANOVA with arm (normal, paralyzed) as withinsubject factor and group (highs, lows) as between-subject factor showed no main effect for arm (normal, $1028 \mathrm{~ms}$; paralyzed, $1057 \mathrm{~ms}$ ), $F(1,30)=$ $0.10, p=.38$, or group (highs, $1044 \mathrm{~ms}$; lows, $1040 \mathrm{~ms}$ ), $F(1,30) \approx 0.0, p=$ .48. There was also no significant interaction between arm and group, $F(1,30)=1.7, p=.10$.

\section{Slope}

A two-way MANOVA with arm (normal, paralyzed) as withinsubject factor and group (highs, lows) as between-subject factor showed no main effect for arm (normal, $4.71 \mathrm{~ms} / \mathrm{deg}$; paralyzed, $4.11 \mathrm{~ms} / \mathrm{deg}$ ), $F(1,30)=0.20, p=.33$, or group (highs, $4.49 \mathrm{~ms} / \mathrm{deg} ;$ lows, $4.31 \mathrm{~ms} / \mathrm{deg}$ ), $F(1,30)=0.01, p=.46$. There was also no significant interaction between arm and group, $F(1,30)=2.48, p=.08$ (see Figure 1).

These results indicate that hypnotic susceptibility does not significantly affect the speed of mental imagery and mental rotation of the arm when it is implicitly cued. Also, high hypnotizables as well as lows failed to show significant slowing in implicit mental imagery and rotation of the paralyzed arm compared to the normal arm.

\section{Explicit Hand-Rotation Task (2)}

The mean $R^{2}$ for the high hypnotizables' regression lines was .60 for the normal and .81 for the paralyzed arm. For lows, the mean $R^{2} s$ were .61 and .40 , respectively.

In $11.5 \%$ (33) of the trials, high hypnotizables reported an inability to imagine the right hand rotating toward the target position, versus $3.5 \%$ (10) by the low hypnotizables. Four highs spontaneously reported feelings of "having to break the arm," "the arm being too heavy," "my arm is not there anymore," or "it just didn't work," respectively, when mentally moving the right arm with a large angle of rotation. Lows did not report such experiences. 

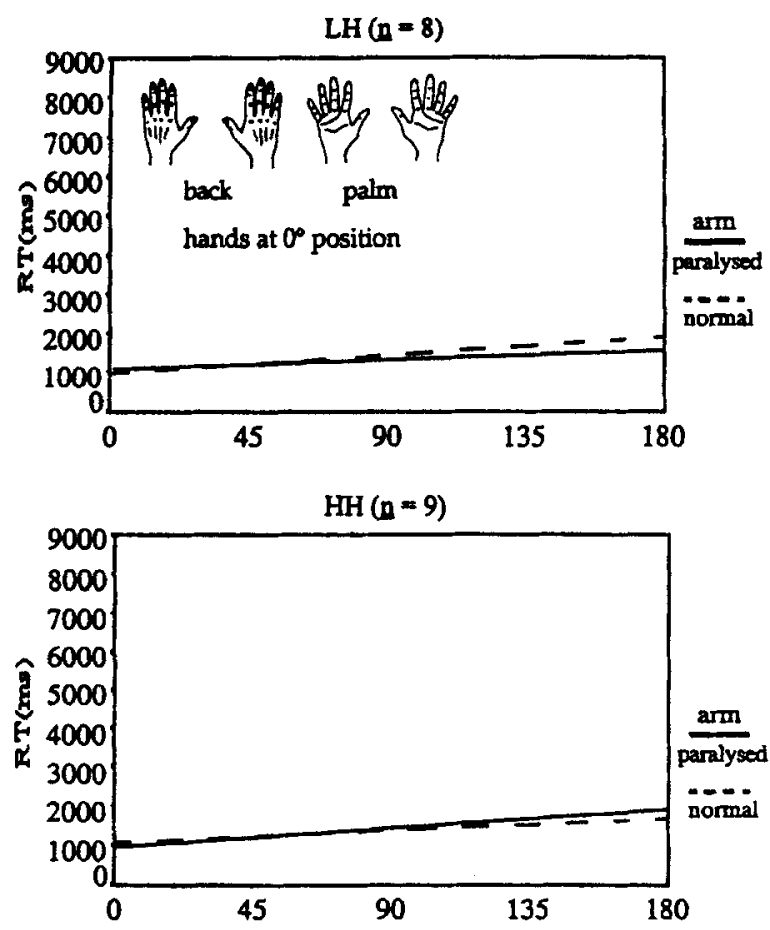

Orientation difference (OD) from upright position $\left(0^{\circ}\right)$ in degrees

Figure 1. Regression lines of implicit mental hand rotations with the normal (left) arm and the paralyzed (right) arm in lows $(n=8)$ and highs $(n=9)$.

Note. $\mathrm{RT}=$ reaction time.

\section{RT Intercept}

A two-way MANOVA with arm as within-subject factor and group as between-subject factor showed a main effect for arm (normal, $2324 \mathrm{~ms}$; paralyzed, $3708 \mathrm{~ms}), F(1,30)=10.97, p<.01$, and group (high, $3440 \mathrm{~ms}$; low, $2561 \mathrm{~ms}), F(1,30)=4.64, p<.05$. There was, however, no significant interaction between arm and group, $F(1,30)=.30, p=.29$.

Slope

A two-way MANOVA with arm as within-subject factor and group as between-subject factor showed no significant main effect for arm on the slope (normal, $7.1 \mathrm{~ms} / \mathrm{deg}$; paralyzed, $13.7 \mathrm{~ms} / \mathrm{deg}$ ), $F(1,30)=2.3, p=$ .07. There was also only a trend for group (high, $6.9 \mathrm{~ms} / \mathrm{deg}$; low, 13.9 $\mathrm{ms} / \mathrm{deg}), F(1,30)=2.7, p=.06$. However, the interaction between arm and group was significant, $F(1,30)=3.9, p<.05$, indicating a slowing for the larger mental rotations with the paralyzed arm in high hypnotizables (see Figure 2). 

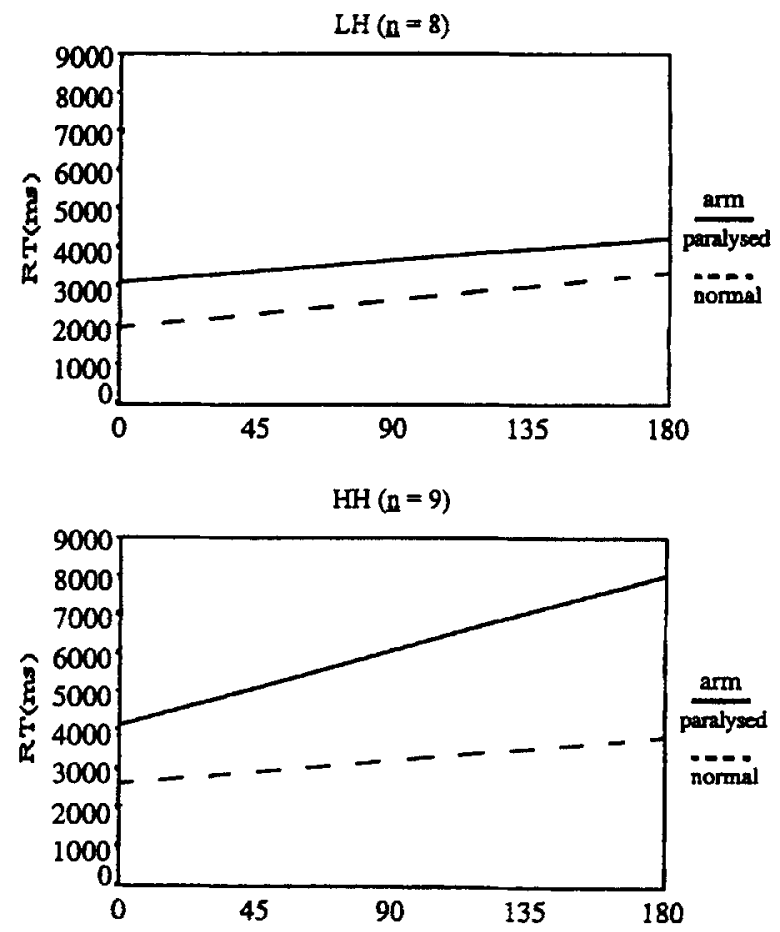

Orientation difference $(O D)$ from upright position $\left(0^{\circ}\right)$ in degrees

Figure 2. Regression lines of explicit mental hand rotations with the normal (left) arm and Note. $\mathrm{RT}=$ reaction time. the paralyzed (right) arm in lows $(n=8)$ and highs $(n=9)$.

These results show that on the explicit task highs were slower than lows in mental imagery of arms and that mental imagery of the paralyzed arm was slower than mental imagery of the normal arm. Furthermore, the slope for explicit mental rotation with the paralyzed hand was significantly larger than the slope for the normal arm in high hypnotizables only (see Figure 2). These findings indicate that, compared to lows, high hypnotizables were slower in mentally rotating their paralyzed arm when the angle of rotation became larger.

\section{DISCUSSION}

The results showed no significant effects of hypnotizability (high, low) and arm (paralyzed, normal) on the RT when mental hand rotations were implicitly cued. On the explicit mental hand-rotation task, however, highs were found to be slower than lows, and mental imagery of the paralyzed arm was also found to be slower than mental imagery of the normal arm. Most important, a significant group by arm interaction 
on the slopes in this task showed that the RT increase per degree of rotation was larger for the paralyzed arm than for the normal arm, and this effect was only observed in the high hypnotizables and not in the lows. Thus, in support of our first hypothesis, we found an asymmetry in motor imagery in highs, with a slowing of the paralyzed arm. And, in agreement with our second hypothesis, this asymmetry was only significant when motor imagery was explicitly instructed. Both findings are consistent with the findings of the previous motor imagery study in patients with conversion paralysis (Roelofs et al., 2001). Patients with conversion paralysis also showed a motor imagery asymmetry with a slowing of the affected arm, again only when the mental hand rotations were explicitly instructed.

Another finding from the explicit task in hypnotic paralysis was that not only highs but also low hypnotizables had larger RT intercepts for the mental imagery of the paralyzed arm than for the normal arm. This is a likely result of the inclusion criterion that all subjects (highs and lows) had to have passed the arm catalepsy item of the SHSS:C. As a result, both lows and highs may have responded with slowed mental imagery to the suggestions of arm paralysis. This explanation is, however, tentative, and it should be investigated whether highs and lows who do not respond to the arm catalepsy item of the SHSS:C would indeed fail to exhibit a slowing in mental imagery of the paralyzed arm.

In contrast to lows, highs had relatively larger slopes for paralyzed arms on the explicit hand-rotation task, indicating that mental rotation of the paralyzed arm was slowed in highs only. These findings may suggest that hypnotic susceptibility has specifically influenced mental movement (hand rotation). The suggestion that hypnotizability influences the way movement is affected by suggestions of paralysis is consistent with the spontaneously reported inability to mentally rotate the right arm into the most extreme target positions in four highs, whereas no low hypnotizables made mention of such a sensation.

The imagery asymmetry observed in hypnotic paralysis resembled the motor imagery profile observed in conversion paralysis, which may indicate that similar mechanisms are involved in suggested and conversion paralysis. The results in both hypnotic and conversion paralysis showed that mental movement is slowed when mental movements are explicitly instructed. This is indicative of an inhibition of movement when movement is intentional and high-level cortical control is involved. These findings are in agreement with the findings of previous studies showing high level control structures, such as the anterior cingulate and the orbito-frontal cortex, to be involved in both hypnotic paralysis (Halligan et al., 2000) and conversion paralysis (Marshall et al., 1997).

Functions of the prefrontal cortex have been conceptualized in terms of an attention control system by Shallice (1988). In his widespread 
hierarchical model, the author described a lower-level action control mechanism and a higher-level Supervisory Attentional System (SAS). According to this model, well-learned behavior is mostly controlled by lower-level action mechanisms. Lower-level action control, for example, involves learned behavioral units, or "schemata," that can be activated by environmental stimuli through a decentralized, rather automatic, process called "contention scheduling" (Shallice, 1988). If it is necessary, or otherwise desirable, the SAS can override this autonomic process.

The present study was designed in such a way that both motor processes that are likely to be controlled by lower-level processes and motor processes that rely more on the SAS could be studied. In Task 1 (the implicit hand-rotation task), the hand identification of visually presented rotated hands is suggested to automatically evoke mental hand rotations (Decety et al., 1994; Lang et al., 1994; Parsons et al., 1995; Porro et al., 1996; Stephan et al., 1995). In Task2, the explicit instruction to mentally rotate the hand to the target position as naturally and as efficiently as possible is likely to evoke more SAS involvement. In this task, the mental hand rotations are intentional instead of incidental. Only in this task we observed a significant slowing in the mental rotation with the paralyzed arm in high hypnotizables. The fact that the suggestion eliciting paralysis was specifically effective in the task that required more executive control may be explained by the involvement of higher executive control functions during hypnosis in highs. The findings of several studies suggest that the activation of frontolimbic inhibitory systems serves to suppress the higher executive control functions of the anterior cingulate cortex in hypnotized subjects (see Gruzelier, 1998; Kallio, Revonsuo, Hämäläinen, Markela, \& Gruzelier, 2001). This change is proposed to result in the suspension of reality testing and to correspond to the handing over of executive and planning functions to the hypnotist. Accordingly, hypnotic suggestions inducing paralysis may result in high-level (SAS) inhibition of lower-level motor processes without the notion of volition. Woody and Sadler (1998) hypothesized that with reduced executive oversight the behavior of a hypnotic subject can be genuinely less volitionally determined than usual. Similar mechanisms may be responsible for the fact that the symptoms in conversion disorder are also experienced as nonvolitional (Oakley, 1999). To explain the similarities between conversion and hypnotic phenomena, Oakley suggested that external influences on the SAS in hypnosis (hetero-suggestion) and internal influences (auto-suggestions) on the SAS in conversion disorder may result in similar symptoms.

The present study has some limitations that need to be addressed. In the first place, the findings should be replicated before definite conclusions can be drawn. The study should therefore be regarded as a first, but promising, step in using RT paradigms in studying the behavioral resemblance between hypnotic and conversion paralysis. Furthermore, 
it remains largely unknown which exact factors contribute to the slowing in mental movement in highs with hypnotic arm paralysis. To investigate to what degree the slowing can be ascribed to an increased responsiveness of high hypnotizables to task demands, a control group of lows instructed to simulate a paralysis of the right arm may shed more light on this issue. Also, to prevent the instructions of the explicit task from influencing the strategy used in the implicit task, the implicit task always preceded the explicit task. As a result, we cannot rule out, for example, the possibility that the second catalepsy induction may systematically have had stronger hypnotic effects than the first one. Such an effect would, however, have affected both groups and is therefore not likely to have influenced the group comparison of the performance differences between the paralyzed and the normal arms. Also, the state of the arm catalepsy was consistently checked after each induction, and the subjective reports by the subjects on sensory changes as well as the (tactile) observations of the hypnotist offered no indication for such a difference. Therefore, a possible difference in the effectiveness of the catalepsy at different times is unlikely to have caused the large differences in the effects found for the implicit and the explicit tasks.

A last remark concerns the implications of our findings. It has frequently been shown that conversion symptoms can be induced using suggestive techniques in highly hypnotizable subjects (see Oakley, 1999). In the ideal situation, when asking a subject with hypnotically induced paralysis to move, he or she will report an inability to move and will show no movement until the reverse is suggested. The findings of the current study are interesting because they show that not only motor execution but also the speed of mental motor representations can be altered by suggestion for paralysis in such a way that it resembles conversion paralysis. These findings do not prove that similar mechanisms are involved in conversion disorder and hypnosis nor that conversion paralysis is caused by self-hypnosis. The findings, however, suggest that both conversion and hypnotic paralysis involve an inhibition on high level of movement preparation.

\section{REFERENCES}

Abelson, R. P. (1995). Statistics as principled argument. Hillsdale, NJ: Lawrence Erlbaum.

American Psychiatric Association. (1994). Diagnostic and statistical manual of mental disorders (4th ed.). Washington, DC: Author.

Annett, M. (1970). Classification of hand preference by association analysis. British Journal of Psychology, 61, 303-321.

Bliss, E. L. (1984). Hysteria and hypnosis. Journal of Nervous and Mental Disease, 172, 203206.

Decety, J., Perani, D., Jeannerod, M., Bettinardi, V., Tadary, B., Woods, R., et al. (1994). Mapping motor representations with positron emission tomography. Nature, 371, 600-602. 
Dominey, P., Decety, J., Broussolle, E., Chazot, G., \& Jeannerod, M. (1995). Motor imagery of lateralized sequential task is asymmetrically slowed in hemi-Parkinson's patients. Neuropsychologia, 33, 727-741.

Gruzelier, J. (1998). A working model of the neurophysiology of hypnosis: A review of the evidence. Contemporary Hypnosis, 15, 3-21.

Hall, C., Pongrac, J., \& Buckholz, E. (1985). The measurement of imagery ability. Human Movement Science, 4, 107-118.

Halligan, P. W., Athwal, B. S., Oakley, D. A., \& Frackowiak, R. S. J. (2000). Imaging hypnotic paralysis: Implications for conversion hysteria. Lancet, 355, 986-987.

Jeannerod, M. (1997). The cognitive neuroscience of action. Oxford, England: Blackwell Publishers.

Kallio, S., Revonsuo, A., Hämäläinen, H., Markela, J., \& Gruzelier, J. (2001). Anterior brain functions and hypnosis: A test of the frontal hypothesis. International Journal of Clinical and Experimental Hypnosis, 49, 95-108.

Kihlstrom, J. F. (1992a). Dissociation and dissociations: A comment on consciousness and cognition. Consciousness and Cognition, 1, 47-53.

Kihlstrom, J. F. (1992b). Dissociative and conversion disorders. In D. J. Stein \& J. E. Young (Eds.), Cognitive science and clinical disorders (pp. 247-270). San Diego, CA: Academic Press.

Lang, W., Petit, L., Höllinger, P., Pietrzyk, U., Tzourio, N., Mazoyer, B., et al. (1994). A positron emission tomography study of oculomotor imagery. Neuro Report, 5, 921-924.

Lauerma, H. (1993). Nocturnal limb movements in conversion paralysis. Journal of Nervous and Mental Disease, 181, 707-708.

Lishman, W. A., \& McMeekan, E. R. L. (1976). Hand preference patterns in psychiatric patients. British Journal of Psychiatry, 129, 158-166.

Marshall, J. C., Halligan, P. W., Fink, G. R., Wade, D. T., \& Frackowiak, R. S. J. (1997). The functional anatomy of a hysterical paralysis. Cognition, 64, B1-B8.

Moene, F. C., Hoogduin, C. A. L., \& Van Dyck, R. (1998). The inpatient treatment of patients suffering from (motor) conversion symptoms: A description of eight cases. The International Joumal of Clinical and Experimental Hypnosis, 46, 171-190.

Näring, G. W. B., Roelofs, K., \& Hoogduin, C. A. L. (2001). The Stanford Hypnotic Susceptibility Scale, Form C: Normative data of a Dutch student sample. Journal of Clinical and Experimental Hypnosis, 49, 139-145.

Nemiah, J. C. (1993). Dissociation, conversion and somatization. In A. Tasman \& S. M. Goldfinger (Eds.), American psychiatric press review (Vol. 10, pp. 248-260). Washington, DC: American Psychiatric Press.

Oakley, D. A. (1999). Hypnosis and conversion hysteria: A unifying model. Cognitive Neuropsychiatry, 4, 243-265.

Parsons, L. M. (1994). Temporal and kinematic properties of motor behavior reflected in mentally simulated action. Journal of Experimental Psychology, Human Perception and Performance, 20, 709-730.

Parsons, L. M., \& Fox, P. T. (1998). The neural basis of implicit movements used in recognising hand shape. Cognitive Neuropsychology, 15, 583-615.

Parsons, L. M., Fox, P. T., Downs, J. H., Glass, T., Hirsch, T. B., Martin, C. C., et al. (1995). Use of implicit motor imagery for visual shape discrimination as revealed by PET. Nature, $375,54-58$.

Parsons, L. M., Gabrieli, J. D. E., Phelps, E. A., \& Gazzaniga, M. S. (1998). Cerebrally lateralized mental representations of hand shape and movement. Joumal of Neuroscience, 18, 6539-6548.

Porro, C. A., Francescato, M. P., Cettolo, V., Diamond, M. E., Baraldi, P., Zuiani, C., et al. (1996). Primary motor and sensory cortex activation during motor performance and motor imagery: A functional magnetic resonance imagery study. Journal of Neuroscience, $16,7688-7698$. 
Roelofs, K., Näring, G. W. B., Keijsers, G. P. J., Hoogduin, C. A. L., van Galen, G. P., \& Maris, E. (2001). Motor imagery in conversion paralysis. Cognitive Neuropsychiatry, 6, 21-40.

Sacerdote, P. (1970). Theory and practice of pain control in malignancy and other protracted or recurring painful illnesses. International Journal of Clinical and Experimental Hypnosis, 18, 160.

Schacter, D. L., \& Kihlstrom, J. F. (1989). Functional amnesia. In F. Boller \& G. J. Graffman (Eds.), Handbook of neuropsychology (Vol. 3, pp. 209-231). Amsterdam: Elsevier Science.

Shallice, T. (1988). From neuropsychology to mental structure. Cambridge, England: Cambridge University Press.

Sheehan, P. W. (1967). A shortened form of Bett's questionnaire upon Mental Imagery. Journal of Clinical Psychology, 23, 386-389.

Shepard, R., \& Cooper, L. (1982). Mental images and their transformations. Cambridge, MA: MIT Press.

Shepard, R. N., \& Metzler, J. (1971). Mental rotation of three-dimensional objects. Science, 171, 171-703.

Spiegel, D. (1990). Hypnosis, dissociation and trauma. In J. L. Singer (Ed.), Repression and dissociation: Implications for personality, theory, psychopathology and health. The John D. and Catherine T. MacArthur Foundation series on mental health and development (pp. 121-142). Chicago: University of Chicago Press.

Stephan, K. M., Fink, G. R., Passingham, R. E., Silbersweig, D., Ceballos-Baumann, A. O., Frith, C. D., et al. (1995). Functional anatomy of the mental representation of upper extremity movements in healthy subjects. Journal of Neurophysiology, 73, 373-386.

Voogd, H. (1995). C_Frame, software for implementing real-time experiments [Computer software]. Downloaded from http://www.nici.kun.nl/ voogd/C_Frame

Weitzenhoffer, A. M., \& Hilgard, E. R. (1962). Stanford Hypnotic Susceptibility Scale, Form C. Palo Alto, CA: Consulting Psychologists Press.

Woody, E., \& Sadler, P. (1998). On reintegrating dissociated theories: Comment on Kirsch and Lynn (1998). Psychological Bulletin, 123, 192-197.

\section{Motorische Vorstellungen bei hypnotisch induzierter Armlähmung von hoch- und niedrigsuggestiblen Versuchspersonen}

\section{Karin Roelofs, Kees A. L. Hoogduin, und Ger P. J. Keijsers}

Zusammenfassung: Bisherige Untersuchungen $\mathrm{zu}$ Konversionsstörungen deuten an, dass Patienten mit Hand/Armlähmung eine verlangsamte Reaktionszeit für mentale, den gelähmten Arm betreffende HandRotationsaufgaben zeigen, wenn die Aufgaben explizit gestellt wurden, aber nicht, wenn sie implizit aufgerufen wurden. Aufgrund der zahlreichen Ähnlichkeiten zwischen hypnotischen Phänomenen und Konversionssymptomen untersuchten die Verfasser, ob ein ähnliches Defizit der motorischen Vorstellung bei normalen hochsuggestiblen Probanden (HH) festzustellen ist, wenn Lähmung suggeriert wird. Neun Hochsuggestible (HH) und acht Niedrigsuggestible (LH) erhielten während einer in Hypnose suggerierten Lähmung des rechten Armes eine implizite und eine explizite mentale Hand-Rotationsaufgabe. Bei der impliziten Aufgabe gab es zwischen den HHs und LHs keine signifikanten Unterschiede der Reaktionszeit (RT). Bei der expliziten Aufgabe zeigten nur die HHs eine signifikant größere Zunahme der Reaktionszeit per Grad der Rotation des gelähmten Arms im Vergleich zum normalen Arm. Diese vorläufigen Ergebnisse deuten an, dass das Defizit der motorischen Vorstellung, das bei 
Konversionslähmung festzustellen ist, bei Hochsuggestiblen durch Hypnose induziert werden kann.

\author{
ROSEMARIE GREENMAN \\ University of Tennessee, Knoxville, TN, USA
}

\begin{abstract}
Imagerie motrice paralysie hypnotique chez des sujets hautement et faiblement hypnotisables
\end{abstract}

\title{
Karin Roelofs, Kees A. L. Hoogduin, et Ger P. J. Keijsers
}

Résumé: Des recherches antérieures suggèrent que les patients porteurs de symptômes de conversion à type de paralysie de la main et du bras avaient des temps de réaction (RT) plus ralentis pour les tâches de rotation mentale de la main correspondant au bras atteint, alors que les tâches étaient bien explicitées; par contre pas de réaction si la tâche était implicitement indiquée. En raison de nombreuses similitudes entre les phénomènes d'hypnose et ceux de conversion, les auteurs ont recherché si la diminution de l'image motrice entrainait une réponse normale parmi les sujets hautement hypnotisables quand la paralysie leur était suggérée. 9 sujets hautement hypnotisables (HHs) et 8 faiblement (LHs) ont reçu une tâche implicite et explicite de rotation mentale pendant une suggestion de paralysie du bras droit. Pendant la tâche implicite il n'y a pas eu de temps de réaction (RT) significatif et HHs et LHs. Pendant la tâche explicite seuls les HHs ont montré un RT significativement plus important de rotation de la main paralysée comparativement au bras normal. Ces résultats préliminaires suggèrent que la diminution de l'imagerie motrice observée dans la paralysie de conversion peut être induite chez les HHs qui utilisent l'hypnose.

\section{VICTOR SIMON \\ Psychosomatic Medicine \& Clinical Hypnosis Institute, Lille, France}

\section{Imágenes de moviemiento durante la parálisis hipnótica de brazo en sujetos con alta y baja hipnotizabilidad}

Karin Roelofs, Kees A. L. Hoogduin, y Ger P. J. Keijsers

Resumen: La investigación previa sugiere que los pacientes con trastorno de conversión con parálisis de mano/ brazo exhiben tiempos de reacción demorados en las pruebas mentales de rotación de la mano que corresponde al brazo afectado cuando las instrucciones de las pruebas son explicitas, en contraste con instrucciones implícitas. A causa de las muchas semejanzas entre los fenómenos hipnóticos y los síntomas de conversión, los autores investigaron si habría un deterioro similar en las imágenes motrices en sujetos normales altamente hipnotizables (AH) después de una sugestión de parálisis. Administramos una tarea de rotación de la mano implícita y una explicita a nueve AHs y ocho con baja hipnotizabilidad (BH) durante la parálisis del brazo derecho sugerida hipnóticamente. En la prueba implícita, no hubo diferencias significativas en el tiempo de reacción (TR) entre los AHs 
y los BHs. En la tarea explícita, sólo los AHs mostraron un aumento significativo de TR por grado de rotación en el brazo paralizado, comparado al brazo normal. Estos resultados preliminares sugieren que se puede inducir hipnóticamente en los $\mathrm{AH}$ el deterioro de imágenes motrices observado en la parálisis de conversión.

ETZEL CARDEÑA

University of Texas, Pan American,

Edinburg, TX, USA 